DOI: 10.38144/TKT.2021.1.7

http://orcid.org/0000-0002-2409-4465

kovacs.ramona@btk.elte.hu

RAMÓNA KOVÁCS

\title{
Pihon yŏsŏng - New Lifestyle and New Choices for Marriage and Unmarried Life in South Korea
}

\section{Introductory remarks}

What decision do people face when getting married in a modern Asian society? At the heart of this question lie traditional attitudes toward marriage (kyorhont'aedo 결혼 태도 結婚態度) which are completely different from those held by Westerners. Therefore, when we discuss issues such as number of marriages, number of single households and low birth rates, it is important that these factors are understood within their own cultural framework. In East Asia, traditional ways of thinking and basic principles and ideologies are markedly different from the West. It is clearly true in the case of South Korea, where an originally patriarchal Confucian society is now facing the problem of extremely low birth rates in conjunction with the appearance of new ways of life. One of these is the main focus of this paper, namely pihon yŏsong, women who remain single by choice.

As one of the "four dragons", South Korea is a proud and well-developed country with a strong presence in the world economy, exporting its goods and services to countries all over the world. However, by taking a closer look at Korean society and reading about its latest problems, we find that it is facing many of the problems experienced by other similarly developed European nations, namely economic imbalances caused by a rapidly aging society, gender inequality, a widening generation gap, youth unemployment, falling rates of marriage, rising divorce rates and an extremely low birth rate. Of course, we might find parallels between these nations regardless of their geographical locations, but we can also point to unique factors which originate from the cultural background of each country. 
The aim of this paper is to examine factors that influence the decisions of young Koreans regarding marriage and establishing a family. It places particular focus on women because these new social trends are more relevant to the cultural changes that have taken place in their lives - their new decisions are the ones which go against the traditional norms, and so receive more criticism than those of men. To these ends, the paper will list some of the new phenomena that have appeared during the last 10-15 years and, towards the end of the paper, address the question of premarital cohabitation in Korea, which even today is viewed by Koreans as an unorthodox way of life and a contentious and quite divisive phenomenon.

The primary purpose of this paper has been to draw a schematic picture of current social issues in South Korea for those who are unfamiliar with this Asian country's ideological background, and furthermore it is hoped that these basic ideas might prove useful for comparative purposes to professionals researching ongoing social change in other Asian countries. Several questions originating from the basic topic of this paper are also raised during the course of the paper but unfortunately could not be discussed thoroughly here.

The main points of the chosen topic relied primarily on the research results and academic papers of Korean researchers and these have been illustrated with statistical data. The author has also inserted some of her acquaintances' experiences, which were collected via personal conversation or online dialogue.

\section{Terminology}

Before starting the discussion, a few terms are listed which might aid analysis when reading academic papers in Korean and which are also often used by news portals and official statements when contemporary issues in Korean society are raised. The most important basic term in the focus of this paper is pihon (비혼 非婚) and mihon (미혼 未婚). Mihon can be understood simply as the opposite of kihon (기혼 既婚), which means 'married'. Generally, mihon is widely used to describe those people who wanted to marry but missed their chance to do so, whereas pihon contains the additional meaning of a situation where one doesn't want to marry. This compares with the word pihonjuŭi (비혼주의 非婚主義), which indicates the new trend of preferring a single lifestyle instead of one of commitment, literally meaning 'principle of not wanting the marriage'.

Manhonhwa (만혼화 晚婚化), one of the most serious issues in contemporary South Korea, means 'tendency to late marriage'. Manhon (만혼 晚婚) itself means 'late marriage', which reflects a phenomenon statistically observed for several years now, especially since 1998. The age of first marriage (ch'ohonyŏl- 
lyŏng 초혼연령 初婚年齡) is constantly increasing for both men and women in Korea. (Its reasons will be discussed below.) It is already a problem that the number of marriages is dropping (1990: 399,000 $\rightarrow$ 2015: 302,800 per year), but moreover, those who marry do so at an older age than in past decades, causing several other difficulties such as decreasing birth rate with an attendant slowing of population growth and the economic effects of these. For women, this age was around 24 in 1990, and rose to 30 in 2015. For men a similar change occurred, changing from 27.8 to 32.6. ${ }^{1}$ According to the Korean Statistical Information Service (KOSIS), in 2019 the average age of first marriage was 30.59 for women and 33.37 for men, ${ }^{2}$ proving that the trend for postponing marriage has not abated yet - and is unlikely to stop in future years either. ${ }^{3}$

The reason is quite simple: according to young people in Korea, the ideal age to get married (kyŏrhon chŏngnyŏnggi 결혼 적령기 結婚適齡期) is not in their 20's anymore as social factors (for example attitude towards roles in the family, less emphasis put on traditional customs, women's participation in social and economic life), education, employment issues, wedding customs and services, and the economy make it impossible. Although differences based on social class, educational background, geographical region, etc. play a role, in the main it is a combination of social factors and individual factors which contribute to the delay of first marriage. ${ }^{4}$

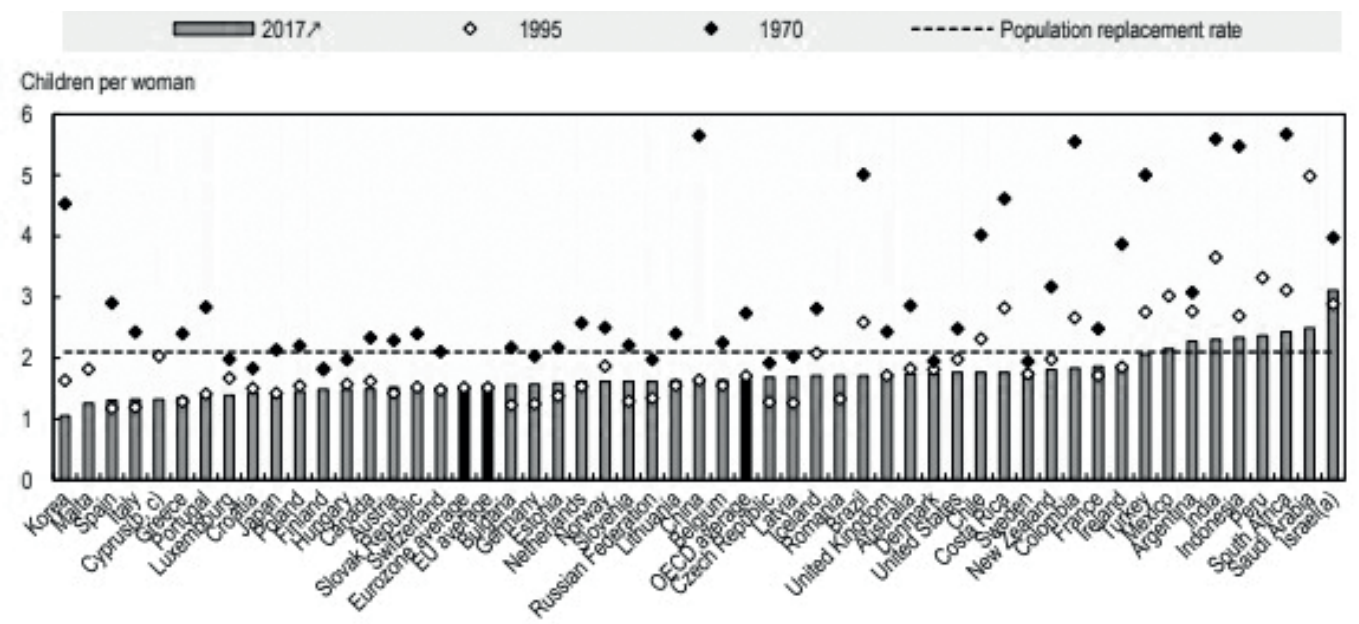

Picture 1. OECD fertility rate. OECD Family Database. http://www.oecd.org/social/family/SF_2_1_Fertility_rates.pdf (03.04.2020.)

1 “[Kŭraep'ik] Honin'gŏnsu mit ch'ohonyŏllyŏng ch'ui.” Joongang Ilbo. 2016.12.13.

2 The answers of my acquaintances confirm the statistics. Only one out of twelve people said 28 as a marriageable age, and only one said 38, the other 10 mentioned the range between 30 35.

${ }^{3}$ Marriage, statistical index, KOSIS.

${ }^{4}$ Kim 2006: 57-60. 


\section{Declining trends of marriage and childbirth - women's responsibility?}

Based on the statistical data of recent years, it is clearly evident that at the present time only about half of the young Korean women consider marriage to be essential. As already mentioned, even if they decide to get married, they usually do so in their 30's, which is a considerable change compared to previous decades. According to a statistic published by the Ministry of Gender Equality and Family in 2017, the age of first marriage for women reached 30,0 in 2016 and is constantly growing. ${ }^{5}$ Marriage itself is interpreted in different ways by Korean women and attitudes towards marriage are also in flux. Researchers who have conducted surveys on these attitudes report opinions from the interviewees such as "I will not live as my mother did", "For women in the Korean society, marriage means more disadvantages than advantages", "If marriage means earning money together and dealing with problems of child rearing, then it'd be better not to do it". In other words, the obligations demanded by the society are in general negatively highlighted, and marriage is characterized as cooperation between a man and a woman to establish a household together, rather than a personal bond between two people who love each other. The pressure not to marry is bigger for women. Traditionally, a wife's assistance (naejo 내조 內助) was one of the main tasks a woman had to complete, while observing numerous rules which regulated the life of a decent woman. ${ }^{6}$ However, decades of modernization has not only changed the economic structure, demography, infrastructure and educational life of South Korea, but also significantly impacted the social structure, roles and lifestyles. ${ }^{7}$ Given the range of new possibilities available to girls and women, they have become less interested and concerned about traditional roles, adopting instead new lifestyles that are displacing marriage as the main form of self-realization. In parallel, Korea is facing the problem of an extremely low birth rate. ${ }^{8}$ Many articles and forums suggest that the problematic birth rate and the decline of marriages are clearly the fault of women who are too selfish to adhere to the traditional gender role. In 2018 the National Assembly Budget Office (국회예산정책처) published an analysis of results with the title The reasons and the economic effects of the low birth rate in Korea (우 리나라 저출산의 원인과 경제적 영향). In this paper, they sought to publicise the factors influencing the decision of the young Koreans by highlighting

5 “"T'onggyero pon yŏsŏng] 'kyŏrhon p'ilsu' mihon yŏ 6nyŏnsae $47 \% \rightarrow 3 \%$." Yonhap news. 2017.06.27.

${ }^{6}$ For details see Kovács 2015: 143-146 and 181-182.

${ }^{7}$ For details about the women's lives during the modernization era see Lee Mijeong 1998. Women's Education, Work and Marriage in Korea. Seoul National University Press.

${ }^{8}$ South Korea became a low birth rate country in 1983, and a super low birth rate country in 2002. 
the necessity to expand facilities for pregnant women, making greater efforts to improve equality between men and women, shortening working hours, and increasing the number of daycare centers and kindergartens, etc. ${ }^{9}$ Currently, the government is in the middle of implementing 5 -year-plans over three periods ${ }^{10}$ until 2020. ${ }^{11}$ While, of course, it is not only South Korea that is in a difficult situation, it is alarming that among the OECD countries Korea has the lowest birth rate. ${ }^{12}$ (Picture 1) Additionally, other countries like the Czech Republic, Japan and Slovakia were able to achieve slightly better numbers in 2016, whereas Korea's fertility rate continued its decline. ${ }^{13}$

Especially since the 2000's, there are several new lifestyle trends appearing in Korean society, and some of these directly influence decision making for marriage and childbirth. In some cases these trends have similar effects on both men and women, but in many cases they have a disproportionate one on women's lives, and thus more fundamentally affect their lifestyle. We will now examine some of the factors one by one.

The trend for living alone. In 1985, only $7 \%$ of the Korean population was considered as a one-person household, but this percentage rose to $24 \%$ by 2010 . Before this, the strong bond between family members, living together under one roof with and in cooperation other generations, was the foundation of the family unit. ${ }^{14}$ But now, education and employment influences the available options for residence as well. If we look specifically at women between the ages of 25 and 34 in a 2010 survey, $66 \%$ of them attended two-year college or four-year university (1980: 7\%) and 62\% attended a regular workplace (1980: 26\%). Many of these girls began to live separately because they had to relocate in order to be able to go to school or work. ${ }^{15}$ With the experience of living on their own came a realization of the positive sides to their independence and accordingly a reluctance to move back together with parents. However, the economic burden of high housing and living costs, sometimes in conjunction with sending a part

9 National Assembly Budget Office 2018: 107-113.

10 The first stage (2006 2010) was to provide better childcare support for low income families, the second (2011 2015) targeted the double income households and the middle class families, while the third period (2016 2020) focused on the support for the young people, including for example the employment of the young, and housing support for newlyweds, etc. Local autonomous entities were involved in several measures as well.

${ }_{11}$ National Assembly Budget Office 2018: vii-viii.

12 Fertility rates. OECD Family Database.

${ }_{13}$ National Assembly Budget Office 2018: 16-19.

14 Park-Choi 2015: 1178-1179.

15 Park-Choi 2015: 1189-1193. 
of their salaries home to support their parents, hinder the continuation of these single households. ${ }^{16}$

Higher educational level. It is observed that the more a girl studies, the later the first marriage commences, this being especially true after 1998. They prefer to take advantage of opportunities to get a higher degree and then, since they have invested so much (time, money, energy) in that achievement, they are not willing to give it all up after a few years, choosing instead to pursue careers with further goals. ${ }^{17}$ Women who complete a full program of education might graduate university with two degrees, focus more on learning languages than is common in other Asian countries, and prepare for entering the world of work. ${ }^{18}$ Consequently, by the time they reach the end of their 20 's, there will have been few chances to get married in the meanwhile. ${ }^{19}$

Employment and career. The type of workplace has a huge impact on the possibility of finding a potential partner. To find a candidate for marriage, working women need a relationship network and this essentially depends on whether it can or cannot originate in the workplace. In some cases, a network of co-workers can help to arrange meetings with potential partners, but in other cases, the rigid working environment and the long working hours place obstacles to forming relationships outside the company. ${ }^{20}$ Additionally, the commitment to the workplace is sometimes not a personal decision, rather a consequence of circumstances. Those women who come from a lower income family may have to support their elderly parents, and consequently do not have extra time or money to find a potential partner. That means, the reasons of working women coming from different background can be different as well. ${ }^{21}$ Nowadays a stable workplace (chigŏbanjŏngsŏng 직업안정성) that provides a constant source of income is one of the top priorities and therefore, until a woman attains a satisfactory workplace position, she may avoid becoming settled as a wife. On the other hand, those girls who start working immediately after high school or finish a two-year college course and gain certification for a certain job might start working full-time earlier, making it possible for them to earn money sooner and to leave the workplace more easily for reasons of marriage and pregnancy. ${ }^{22}$

16 Park-Choi 2015: 1201-1202.

17 Lee-Kim 2015: 42-45.

${ }^{18}$ In South Korea, there is a so-called employment examination (ch'wijik shihŏm 취직 시 험). Many companies use it as a selection stage for choosing and testing the applicants, and they organize it once a year. This means, if somebody wants to enter a specific company or sector and they cannot pass the test, they have to wait for a whole year before they can apply again.

${ }^{19}$ Lee-Kim 2015: 50-55.

${ }^{20}$ Lee-Kim 2015: 48-49.

${ }^{21}$ Lee-Kim 2015: 42-45.

${ }^{22}$ Lee-Kim 2015: 50-55. 
These women work to make a financial contribution for their future lives, while those who graduate with higher levels of education do so for self-realization (chaashirhyon 자아실현). They are motivated to be successful at what they do and may wish to be equal to their (future) spouse at the level of income and position as well. ${ }^{23}$ However, we should not conclude that these status-driven reasons for employment are the only ones to have a negative effect on marriage decisions. In the 2000's, the number of two income couples have been constantly rising because the income of one person is no longer enough to maintain the financial outgoings of the whole family. Although in the past part-time work was preferred for women, recently the full-time working mom has not only made an appearance but also become widespread. ${ }^{24}$ From this perspective, a woman with skills and who has graduated from a good institution can get wellpaid employment and thus contributes to the household more - in other words her suitability as a wife is derived from these economic characteristics. ${ }^{25}$ Here I would like to add a personal comment regarding several stories I heard from a Korean woman who is in her 30's now and participated in multiple 'blind dates ${ }^{26}$ at the bequest of her parents. She was disappointed after experiencing inquiries about her precise income, a question which came up almost every time at these first meetings. She explained that in one meeting her date even told her that he found it rational to ask about the financial issues at the beginning of the date because good numbers created a win-win situation for both parties.

Work and household responsibilities have to be in a balance because, even though the traditional gender roles are fading, childcare and household management still remains the wife's responsibility. This 'second shift' can cause serious difficulties for maintaining her performance in the workplace and is precisely why many Korean women quit their workplace eventually. ${ }^{27}$ Fortunately, we can see a positive change in the attitude of young husbands.

Partner's attitude towards childrearing. In a male-centered society like South Korea, discussion about the father's role in childrearing is a quite new phenomenon. Nonetheless, nowadays it is gaining more and more in popularity. Academic papers and social platforms such as blogs and online articles often discuss the father's participation in childrearing. Although many people still think that taking care of a child is essentially the mother's responsibility, attitudes are changing especially among young Koreans. For instance, in a survey

${ }^{23}$ Lee-Kim 2015: 55-59.

${ }^{24}$ Lee 2008: 175-176.

${ }^{25}$ Lee 2008: 180-181.

26 Sogaet'ing 소개팅 is usually an arranged meeting for two people who haven't met before, but who have a common friend or their meeting is arranged by an agency.

${ }^{27}$ Lee 2008: 181-182. 
executed in 2016, all the participants answered that a father had to take part in childrearing for various reasons. These were the belief that in general it is the task of both parents, that the two income couples should share the responsibilities of the home, and that it is good for children's development. On this last point there is a belief that changes in society have resulted in an expectation that a young father should be interested in his children's daily life not only as a financial supporter, but also as an active participant who shows interest, affection and spends time playing with them. We need to note, that the importance of these factors differs according to single income and two income families. Despite increased awareness and acknowledgement of the importance of the father's role, actual circumstances still prevent its realization. The workplace, lack of time, exhaustion, lack of knowledge and lack of interest adversely affect participation rates, and also around $8 \%$ of Koreans still maintain it is not even the father's task. In the survey, they also mention several times that more information and education is needed for fathers regarding questions related to childrearing because, even if they have time to spend together with their children, many lack knowledge about how to interact with them and how to take care of them. ${ }^{28}$ Relevant here is the traditional cultural background of Korean men, whose influence probably extends well into the second half of the $20^{\text {th }}$ century. This saw sons raised differently from daughters, the former being raised to be good mothers and wives the latter to be responsible bread winners. Therefore, Korean males not only lack positive images of male child-rearing but also even a basic concept of one.

Overcoming these cultural and social impediments to more equal childrearing roles between men and women requires the application of social policy interventions, for example, producing educational material and programs for modern-day fatherhood. Furthermore, in order to ensure their success, government will need to change the atmosphere and attitudes in the workplace by introducing beneficial measures and strengthening the motivation from different sources, like financial and social support from company leaders and communities. ${ }^{29}$ The simple story that follows highlights the type of workplace dilemma that educational programs might help to resolve. Co-workers in an architectural company came into conflict with a female co-worker who had to go home to take care of her children. She had already asked the boss several times to allow her to leave without completing her overtime work. Male co-workers felt that, by being allowed to go home earlier (and here earlier meant leaving the workplace at the end of the regular working hours without overtime), their female co-worker was receiving an unfair privilege. However, when the question "what

${ }^{28}$ Park-Ko 2018: 203-206.

${ }^{29}$ Park-Ko 2018: 209-211. 
is your wife doing right now?" was raised, the answer was: "She is at home taking care of our children of course". Here we can see double standards at play. For the male co-worker (as a single breadwinner), it was simply natural that his wife stayed at home, but he felt entitled to criticize others trying to attain a similar situation (in the context of a two income family). ${ }^{30}$ This anecdote illustrates a common and problematic issue, the different point of view regarding a given situation; Korean working mothers may have to fight for their acceptance both inside the family and the workplace, and modern fathers who may want to participate in their children's childhood actively might face similar problems and conflicts.

We can conclude that two income married couples who share both the household responsibilities and the childcare do so because the man is more likely to understand a working mother's double burden and consequently, participate more actively in their children's daily life. In most cases, the father is a partner to play with, someone to take the child for outdoor activities, excursions and cultural experiences, but who is not yet ready to give advice, to lead their children's thoughts on studies or everyday life decisions. Nowadays, young fathers show interest in their children's personal concerns but they are at an early stage of fulfilling this role. Of course, different factors like work system, educational background, and family background also influence a father's participation. ${ }^{31}$

Considering the current situation and judgments on a father's participation in child-rearing, it is understandable that women may find accepting the role of a wife to be a daunting proposition. In many cases it requires that she ends her career and any further self-cultivation due to the fact that it is socially unacceptable for a woman to deny her responsibilities as a mother. In contrast to this, despite the growing social awareness of the importance of a father's participation, it remains acceptable if a man fails to participate actively in child-rearing. Such double standards can also discourage women from starting a family.

Financial issues. In Korea, there is one specific preparation to start married life - this is honsu (혼수 婚需), which traditionally refers to all the household goods that may be needed after a married couple move in together. ${ }^{32}$ Nowadays it is still a custom, but its evaluation can vary from family to family. There are some who think of it as a practical contribution to the newly wedded life, while others have higher expectations which can lead to conflicts or in severe cases

30 Personal conversation, 2015.

31 Lee-An 2017: 48-53.

${ }^{32}$ In the past, the items included in the honsu depended on the type domestic arrangements that were customary in different historical eras, for example, living with the wife's family's house, living at the husband's family's house, and establishing a new home separately. In most cases, the woman had to prepare mainly clothes and textile goods which could be used after moving in with the in-laws, and that meant some economic support for that household as well. 
even result in divorce. ${ }^{33}$ Actually, the amount of time and money that is spent on preparing every item is considerable, and this is due to particular standards and rules which have to be strictly followed if the marriage preparations are to be fulfilled properly (olbarŭn kyŏrhon chunbi 올바른 결혼 준비). The in-laws can be quite fussy and strict about what they receive as honsu and it is not uncommon for women to listen to the complaints of their in-laws regarding honsu, sometimes even years after the marriage day. Concurrently, the future husband is responsible for buying the house itself and also faces significant financial burden if he cannot afford to do so without a loan or the help of his parents. ${ }^{34}$ Recently, more and more couples decide to solve these marriage preparations as a joint project, sharing the financial burden between themselves and without involving the parents. Naturally, given their age, many newlyweds do not have enough money and so require a loan. Nowadays it is more common for married couples to pay back any loans together and this is especially true in the case of two income families. Even though attitudes are changing, a lot of young women see such loans as a heavy burden and this is also mentioned as a negative factor when considering marriage. ${ }^{35}$ Another factor that can raise the cost of a wedding is when honsu is accompanied by yemul (예물 禮物) and yedan (예단 禮緞). The former is a wedding gift to the future spouse, and the latter is a wedding gift to the future spouse's family. In many cases, when young Koreans don't agree with this additional aspect of honsu, either finding this further duplication of gifts unnecessary or preferring the finances of a smaller wedding, they opt for unmarried life instead. Furthermore, the costs of a wedding can rise due to the size of the wedding party. Due to family bonds still being strong among the older generations, the idea of the small wedding has not gained widespread acceptance in Korea yet. Consequently, wedding parties are swollen by a parent's natural inclination to invite many relatives, co-workers and acquaintances to their child's wedding regardless of whether they have actually met the bride or groom before. Modern-minded young men and women, however, are not so fond of entertaining total strangers anymore and accordingly go against their parents' wishes by minimizing guests to a circle of close relatives and real friends. ${ }^{36}$ Conclusively, they can either take matters into their own hands to avoid ending up as wedding poor, or choose the unmarried lifestyle. ${ }^{37}$

33 "Honsu." Encyclopedia of Korean Culture.

${ }^{34}$ Lee-Kim 2015: 59-61.

35 "Namjanŭn chip, yŏjanŭn honsu? 'olbarŭn kyŏrhon chunbi'e taehan saenggakŭn ..." dongA.com. 2018.06.14.

36 "Namŭn chip, yŏnŭn honsu? mihonnamnyŏ modu 'twaetkŏdŭnyo'." Chosun. 2016.07.13.

${ }^{37}$ Lee-Kim 2015: 74-76. 
In order to gather data on attitudes toward marriage in contemporary Korea, I myself interviewed some young Korean women (between age 28 and 38). According to my respondents, one of the main reasons young people don't get married is the financial factor - to cover all the costs of a traditional wedding, a couple would need 3억 4억 won (300 400 million won), which is more than 300,000 USD. Making matters worse, (Picture 2) South Korea is in the middle of an unemployment crisis and full-time entry level employment with a permanent contract, a prerequisite for saving money, is extremely hard to find.

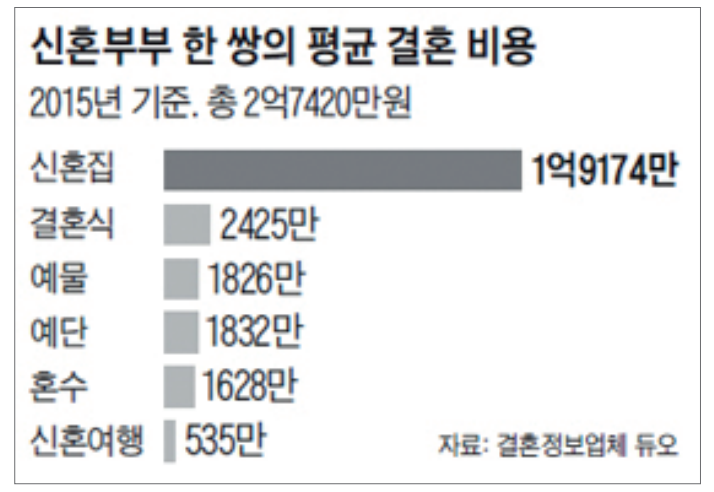

Picture 2. Average cost of marriage

男은 집, 女는 혼수? 미혼남녀 모두 “됐거든요” Chosun Ilbo.

https://news.chosun.com/site/data/html_dir/2016/07/13/2016071300278.html (28.03.2020.)

(New home, wedding, present for future spouse, present for future in-laws, honsu, honeymoon)

Confucian norms vs. me-time. The new socioeconomic status of gold miss ${ }^{38}$ was a frequently discussed issue in Korea ${ }^{39}$ about 10 years ago. This was due to a rapid rise in the number of such women who choose a single life over marriage. A gold miss is a woman who has graduated university and has a stable job with a high wage and consequently, lives an independent life without the need to rely on anyone else. A gold miss is financially unconstrained, living in good circumstances and with disposable income for leisure, material goods and so forth. ${ }^{40}$ This lifestyle is the opposite of the traditional gender role prescribed by

${ }^{38}$ The term comes from 'old miss' which originally indicated a woman who couldn't marry.

39 The phenomenon is not only Korea-specific, it can be observed in other developed Asian countries, like Japan, Taiwan.

40 There is a term silver miss, meaning an unmarried woman in her 30's, but with a less well-paying job and less stable life level, so she cannot afford all the luxury a gold miss can. A silver miss soon regrets not getting married on time. ("Koltŭmisŭ' twie karyŏjin 'shilbŏmisŭ'." Herald Economics 2010.04.05.) 
Confucian ethics ${ }^{41}$ In general, unmarried women can be criticised or blamed for not being able to meet the expectations of a man, but for the gold miss this is not the case for they choose not to marry and thus their decision cannot be construed as failure. Young Korean women, unlike their mothers or grandmothers, now have the opportunity to attend tertiary educational institutes to build a career and then travel easily around the world and therefore, living alone is a positive way of life for them. ${ }^{42}$ In South Korea's modern consumer-based society they are prospective customers for the fashion, food, and cultural industry, while services such as car companies, travel agencies and many others vie for their business with customized products as well. ${ }^{43}$

Of course, not every unmarried Korean women can attain such high standards of living and count herself as a gold miss. Nonetheless, for many of women keeping their freedom is an end in itself. During the talks I had with young Korean women, in answer to the question 'what is the disadvantage of the married life?' half of them replied the lack of 'me-time'. To the question 'what is the advantage of unmarried life?' more than $90 \%$ answered 'freedom', but as a disadvantage they mainly mentioned loneliness and instability.

Still, we can observe the weakening of the Confucian norms. Since traditional Korean society was based on patriarchy, girls were always subordinated to other men, either the father or the husband. They had to follow the traditional customs which prescribed the rules of meeting with other people, activities, obligations and relationship principles. A woman's primary role was to give birth to offspring, preferably a boy. There were other strict rules whose purpose was to engender perfect behaviour. For example, women were not allowed to chat too much, to interfere in men's issues, to show jealousy (even at the time of Chosón polygamy),$^{44}$ and additionally they had to serve their in-laws humbly. To achieve a full and purposeful life, the main life path was to get married and become a mother. ${ }^{45}$ Many of these principles were still followed by the generations living in the second half of the $20^{\text {th }}$ century, but nowadays it is different. Although self-realization is still achieved through married life and motherhood, counter cultural forces are evident in women who are constantly fighting for gender equality in society, primarily in their personal relationships and in the workplace. Respecting and helping the in-laws may be still expected, but in contrast with the Chosonn society, the husband's and the wife's family members

${ }^{41}$ Hwang 2015: 534-538.

${ }^{42}$ Lee-Kim 2015: 74-76.

${ }^{43}$ Park-An 2008. The Korea Times.

${ }^{44}$ During the Chosŏn era (1392-1897), Confucian ideology dominated all the aspects of social life, regulated the hierarchy and prescribed every position's roles. In marriage, especially in the higher classes, polygamy was accepted, meaning a man could have more than one wife.

${ }^{45}$ Kovács 2015: 143-146 and 181-182. 
are not distinguished. Women prefer to decide about the important matters of their life for themselves and this results in a tendency not to follow the norms of the older generations.

\section{New social phenomena}

Continuing the thoughts of the last paragraph, the clash of old and new traditions give some sense of the paradoxical notions circulating in contemporary Korean society. To the outside observer, South Korea is an advanced and highly technological superpower, largely based on outstanding educational achievement and a disciplined society. However, there is actually a pressing need to overcome the tensions that have built up between the flawed perspectives on personal relationships and modern ways of thinking. Even though the typical female figure has changed greatly compared to the beginning of the $20^{\text {th }}$ century, traditional principles still influence the judgment of the older generations. Through the act of childrearing, primary socialization and so forth, this old-fashioned thinking can be transferred to younger generations, resulting in an exceedingly slow rate of social change. A wide generational gap generates conflicts between family members because the youngsters, who are already adjusted to a modernized lifestyle and way of thinking, have to fight for their own decisions to be accepted within their family. This contradiction can also be considered as one of the factors why newlywed couples prefer to live separately from their parents and to start their married life independently (consequently, the nuclear family model is becoming more and more widespread). Furthermore, such differences of opinion appear in workplaces. Citing a personal example, the experience of one of my Korean friends, who is in her 30's and not yet married, is quite telling. She spent several months in Canada at the end of her 20's to gain some life experiences strengthening her English language skills and experiencing life outside Korea. On returning home, she found the majority of her contemporaries were married or preparing for marriage and starting a family. She recounted how she had to face social awkwardness each time they had a gathering because those who were married or in the throes of marriage often insisted that she should hurry up before it became too late. They were unable to understand her alternative views on a happy life, one which required postponing early marriage for the enjoyment of time spent abroad, gaining more professional experiences and the benefits of new experiences. Before long these topics of conversation became exhausted as she hated hearing the repeated suggestions for potential husbands or references to her 'time wasting'. What does this story illustrate? Clearly, differences in attitudes to marriage originate not only from ageist ideas but furthermore, may 
be connected to family background, personal experiences and the expectations of the surrounding society.

Besides the gold miss, we can discuss several new phenomena in the $21^{\text {st }}$ century which are also related to the pihon yŏsŏng, namely 'unmarried women'. It is interesting to observe how the Korean language invents expressions to capture modern-day social issues. These are called shinjoo 신조어 (neologism). To mention a few of these neologisms, we can start with chok'ababo 조카바 보, which means 'crazy for niece or nephew'. This word describes a tendency for single women who have no children of their own to show affection for their nieces or nephews, spending much time and money on them and bragging about them to others as if these children were their own. It is possible to combine this expression with the already discussed gold miss, resulting in the term gold aunt (골드앤트) (or gold uncle in the case of men). A similar tendency also appears in childless couples, who also spend a lot of time with their nieces and nephews. This love towards nieces and nephews influences shopping habits as well, driving them to spend more money on gifts for birthdays or children's days. ${ }^{46}$ Sometimes this desire can be strong and behaviour can be extreme, resulting in what is called chok'ababo syndrome. ${ }^{47}$ A similar phenomenon can be observed in Japan, where a new expression 'eight pocket' (에 잇포켓) is used to describe a situation where an only child benefits from parents and grandparents from both sides of the family as well as uncles and aunts, all of whom spend time and money on him/her. ${ }^{48}$

In the popular media, the word pihaengsonyo 비행소녀 first appeared in 2017 (Picture 3) when a Korean channel presented a program featuring unmarried female stars who said they are completely satisfied with their single lifestyle and had no intention of marrying at all. ${ }^{49}$ The word pihaeng is actually a combination of pihon (not married) and haengbok (happiness), so the expression literally means 'unmarried happy girl'. Given their age, it is remarkable how positively they evaluate their unmarried life - in contrast to the traditional views. ${ }^{50}$ Some-

46 Orininal 어린이날 is children's day, celebrated in Korea on the $5^{\text {th }}$ May since 1923. In its first year, it was established with the motto "씩씩하고 참된 소년이 됩시다. 그리고 늘 서로 사랑하며 도와갑시다", saying "Let's be brave and sincere children. And let's always love and help each other". Even today, it is a much enjoyed festive day with various events ("Orininal" Encyclopedia of Korean Culture).

47 "Shinggŭlchogege nae chashikkat'ŭn kŭ aet't 'chok'ababo' shindŭrom." Asian Economy. 2016.06.13.

48 “Chok'aege p'uk ppajin shinggŭltŭl, chok'ababo shindŭrom!” Life and talk. 2016.06.20.

49 The reality program was aired between 2017.09.07. - 2018. 07.13., with a total of 46 episodes showing the everyday life of famous Korean women. The publicity poster for the program undoubtedly presented this type of lifestyle in a positive way. (MBN)

50 “'Pihaengsonyŏ' Kim Wansŏn, tebwi 33nyŏn mane chip ilsang ch'ŏt konggae 'pihon sam koengjanghi haengbok manjok'." Joongang Ilbo. 2018.04.02. 
body who didn't or couldn't get married at the proper age (chǒktanghan nai 적 당한 나이) was previously stigmatized by society, as it was assumed something was not acceptable with the woman in question. ${ }^{51}$ In the program their reasons for an unmarried life were similar: they preferred focusing on their work, they needed their 'me-time' for self-cultivation, they were comfortably accustomed to living alone, or they wanted to marry only if they found a compatible partner. When the ideal partner did not materialise and they grew older, they might have to give up on the idea of marriage and motherhood forever. Nonetheless, this did not result in failure for them. ${ }^{52}$

Not couldn't marry, but don't want to marry?

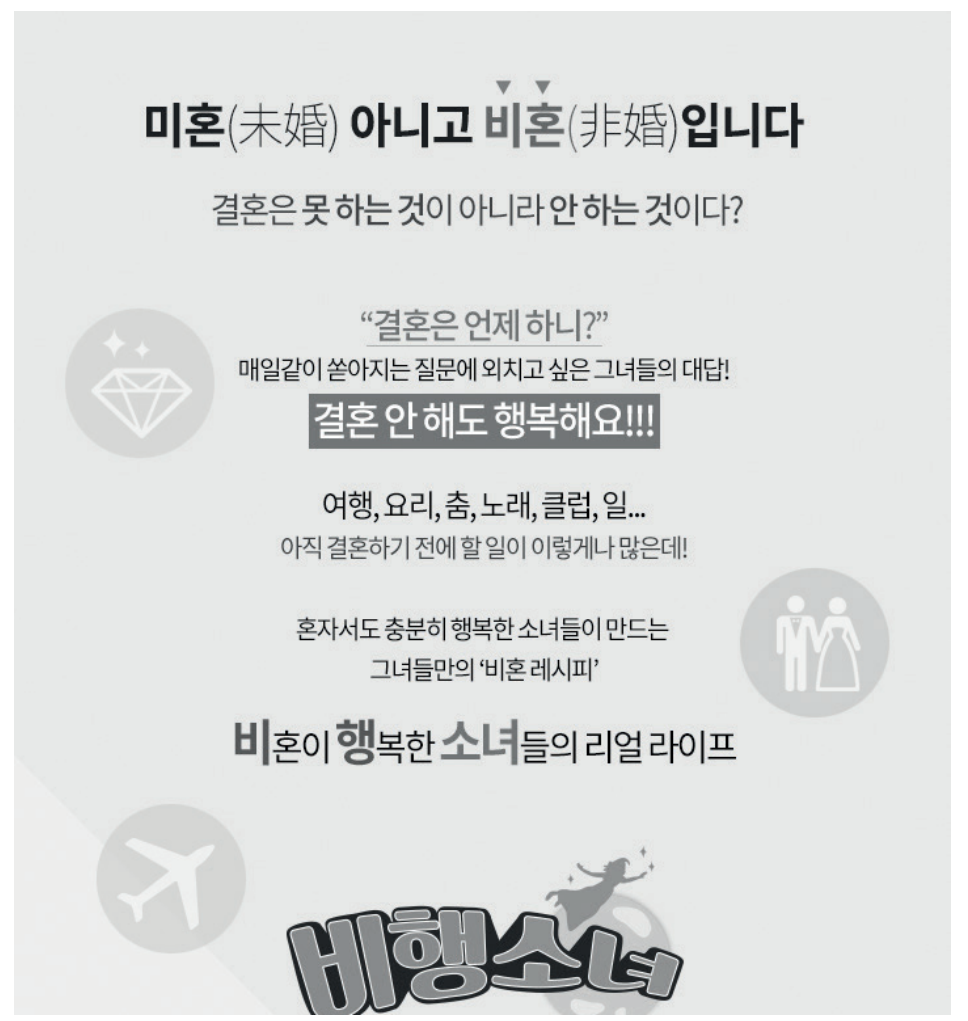

Picture 3. I am not mihon, I am a pihon

MBN program information. https://www.mbn.co.kr/vod/programContents/746/4767

(28.03.2020.)

"When are you planning to get married?"

${ }^{51}$ Lee-Kim 2015: 61-64.

52 "Pihon mwŏgillae? 'Pihaengsonyŏ' ayumi ·chomiryŏng ·ch'oeyŏjin 'kyŏrhon? an han kŏt'." dongA.com. 2017.09.05. 
Here is the answer of those women who get this question every day. I am happy, even if I am not married!!!

Travel, cooking, dance, songs, club, work...

There are so many things I would do before getting married!

Here is the 'recipe' of those women who can live quite happily alone.

Youngsters are slowly changing their mind about customs related to marriage and weddings as well. For example, traditional money gifts for happy occasions (ch'ugŭigŭm 축의금) are now widely discussed by netizens. In South Korea, money gifts usually involve guests handing over an envelope of money to the wedding couple when they attend a wedding. The name of the giver along with their exact amount is registered on a list by the wedding couple. In this way, whenever they attend the wedding of a guest who attended their own wedding, they can return to them an amount of money similar to the amount they received on their wedding day from that guest. Consequently, money gifts represent a zero sum exchange. However, since more and more young people are deciding not to marry, when they do attend weddings and give money as a present they can never get it returned in the traditional way. To solve this problem, there are already people who agree to collect money for their unmarried friends after 10 or 15 years to rebalance the monetary value of the gifts given and received, and this money compensation benefit is called wirogŭm 위로금 instead. ${ }^{53}$

These new trends in Korea's rapidly changing society are followed with interest and ease by the world of services and online groups. In Korea we can find the Unnie network, a group supportive of women which incorporates feminist ideals in its statement of purpose and site description with such keywords as sister love, cultural movement, networking. Their mission is to create a network for women, regardless of skin colour, gender identity, age, economic background or regional origin, with the purpose of establishing a group to fight against discrimination and help women to fulfil their dreams in different fields. Additionally, the site facilitates sincere discussion among women with regard to familiar problems they face, both large and small, including sexual harassment as well. Events, seminars, courses, publishing periodicals and books, etc. are organized and their website offers a special menu for and about unmarried women, which presents outstanding female figures from the past like Simone de

53 “[Pihon ŭi kyŏngjehak] Kyŏrhon? chashik? nae salmi chungyohajyo.” Joongang Ilbo. 2016.07.10. 
Beauvoir, Alekszandra Mihajlovna Kollontaj, Kim Iryeop, ${ }^{54} \mathrm{Na}$ Hyesok,,${ }^{55}$ Lee Tai-young, ${ }^{56}$ Chung Chilsung, ${ }^{57}$ and more. ${ }^{58}$

There are other services that are more socially shocking than internet support groups - these are the photographic studios which target single Koreans who are choosing sologomy. Pihonsik 비혼식 is an event organized for a single person who has chosen not to marry and wants to celebrate their decision with family and friends. Single weddings (싱 글 웨딩) involve no other person but a single bride (or groom), who goes to a photo studio with a beautiful dress, nice hairstyle and makeup to have a photo shoot (스드메 = 스튜디오·드레스·메이크업, sŭdüme [acronym] = studio plus dress plus makeup). ${ }^{59}$ They want to have these photos as a memory and they need to take them while they are young. Even if they never have a real marriage, they want to experience the feeling of wearing a wedding dress, which remains a nice fantasy for many girls. The owners of these studios report seeing this as an increasing tendency. Many people were too shy and ashamed to visit a studio some years ago, however, nowadays the average number of photo shoots per week is constantly growing. ${ }^{60}$

As a consequence of these new phenomena, a new group of consumers is forming. These are the ones who live in one-person households and whose purchasing habits reflect a closer attention to the interior of their home, self-cultivation, hobbies, leisure. (Those who can't afford their own residence, in many cases live together with flat mates.) The real estate market is also paying attention to their needs. ${ }^{61}$

\section{Living together before marriage}

The issue of premarital cohabitation (honjŏndonggŏ 혼전동거 婚前同居) in South Korea, as a social question that concerns many in and outside Korea, is clearly a topic for a paper all of its own, Here I would like to simply present the basic notions and problems regarding the generational gap on this issue in Korea.

54 김일엽 (1896-1971) Buddhist nun, writer, poet, activist.

55 나혜석 (1896-1948) painter, sculptor, activist.

56 이태영 (1914-1998) lawyer, activist.

57 정칠성 (1897-1958?) dancer, activist.

58 Unni network website.

59 “"Nanŭn nawa kyŏrhonhanda'... shinggŭrweding sŏnt'aek'anŭn 'sollogomijok'." Asian Economy. 2018.03.22.

60 ““Namp'yŏn ŏpsŏdo kwaench'ana' nahollo kyŏrhonhanŭn 'shinggŭrwedingjok'.” Money today. 2015.07.10.

${ }_{61}$ "[Pihon ŭi kyŏngjehak] Kyŏrhon? chashik? nae salmi chungyohajyo." Joongang Ilbo. 2016.07.10. 
Differences of opinion regarding marriage beliefs are under pressure because the percentage of the younger generation who accept cohabitation before marriage is constantly growing, in spite of the fact that it was unimaginable even a few decades ago. Parents still have a strong influence on their children's decision regarding marriage, and this extends to cohabitation as well. In a common case, if parents are decidedly against cohabitation, it will not even occur to the young couple to attempt it without permission. Nonetheless, the aforementioned problems and difficulties that affect young people's everyday lives drive them to try new things, in the hope that these may provide solutions or at least a helpful alternative. Premarital cohabitation falls exactly into this category.

It is important to distinguish pihondonggo (비혼동거 同居). This refers to two people who are living together as a couple or life partners, but who don't plan to marry at all. Although pihondonggo is not so common, it is slowly spreading as a way of life. This alternative 'family type' is not simply one of convenience but also an expression of current society as well. ${ }^{62}$

Among the definitions, we may meet the term 'precursor to marriage cohabitation' (yebidonggo 예비동거 豫備同居). It aims to reveal the compatibility of a future husband and wife who have already decided to get married. ${ }^{63}$ But in most cases, there is no firm decision on the subject of marriage yet; they simply decide to move in together and start a life with somebody they like without the pressure of marriage customs, obligations and family issues - the critical point here is that they may have to do this in secret, meaning that the parents and relatives remain unaware if possible. As I have heard from Koreans, sometimes it is not enough to move far away from the people who might criticize this decision. The couple must pay attention to the neighborhood as well, because if conservative-minded people live next door, they can also interfere and start conflicts.

Often, cohabitation is a test before the first marriage or it is a new alternative to couples living separately. In more and more cases though, it provides a path for those who have already quit a failed marriage via divorce and choose cohabitation before remarrying. (Detailed research takes other factors into consideration such as educational background, age group, family background, employment status, etc. ${ }^{64}$ It can be observed that the ratio of cohabiting households is increasing in line with the rise in divorce rates. Those couples who decide to live their lives together in cohabitation in general or try cohabitation before getting married are living in a more healthy relationship because gender equality is achieved more naturally and easily within them. (Sometimes the tra-

$62 \mathrm{Yu}$ 2015: 86.

${ }^{63}$ Lee 2008: 80.

${ }^{64}$ Lee 2008: 97. 
ditional gender roles' reversal might happen as well. ${ }^{65}$ Cohabitation is usually more influential in the lives of women because it guides their decisions more strongly. Premarital cohabitation means also having sex before marriage, which is still generally seen as a taboo. Moreover, cohabitation does not necessarily lead to marriage as the experiences gathered during the cohabitation period might make the man or woman reconsider their future plans and sometimes result in the cancellation of wedding plans, although this is actually a positive outcome in a way as it prevents a possible divorce. ${ }^{66}$

To understand the cohabitation issue in Korea, it is important to take a range of factors into consideration: thoughts on marriage within the given society, negative judgments on children born out of wedlock ${ }^{67}$ acceptance of criticism from family members, gender roles and financial management of the cohabiting couple, relationship to the future in-laws, and last but not least, notions of family itself. This last one can regard to the question of children, or in today's society to pets as well. ${ }^{68}$ To draw a full picture of the nature of premarital cohabitation, naturally requires a fuller and more detailed discussion of this topic.

\section{Closing remarks}

The topic of this paper has focused on current questions surrounding marriage and the rise in single lifestyles, from the point of view of Korean women. As we can see from research, statistics and anecdotal sources as well, contemporary Korean society is now facing several declines which generate a series of problems. Nowadays it is not only academic researchers who are eager to reveal all the relevant data regarding the novel decisions of young Korean, but also the government, which is paying particular attention to new developments affecting young Koreans because their decisions may well have a direct influence on economic, demographic and social aspects of South Korean society. There is an urgent need to find a solution to encourage not only women, but also men to find happiness and stability inside a healthy relationship, but the issue is more complex. Clearly, we need to analyse all these factors within the frame of Korean ways of thinking and customs. However, as Western researchers it may be useful to make comparisons with European societies because, in general, the above mentioned difficulties are not unique to South Korea indeed several developed nations are fighting with the same problems.

\footnotetext{
65 Lee 2008: 98.

66 Kim 2006: 63-66.

67 Kim 2006: 66-68.

68 Yu 2015: 88-96.
} 
As for Korea, first steps should give priority to developing women's facilities and daycare centers, disseminating educational material on child care and child-rearing for men, encouraging companies to think over their policies toward female employees especially those with or intending to have children, re-evaluating Confucian norms and confirming their actuality in the $21^{\text {st }}$ century. Unfortunately, only when sexist atmospheres inside workplaces and the dominant ideas held by society about family formation and gender roles change sufficiently, will new laws or measures have their desired effect.

This paper has discussed several questions and presented some of the new phenomena related to pihon yŏsŏng, yet there are still many more to be discussed and analysed. I hope this overview and summary will assist further research, comparison and evaluation on the topic of unmarried young Koreans.

\section{References}

\section{Secondary sources}

Hwang, Jisoo 2015. "Housewife, 'Gold Miss,' and Equal: The Evolution of Educated Women's Role in Asia and the U.S." Journal of Population Economics (Springer; European Society for Population Economics) 29.2: 529-570. https://doi.org/10.1007/s00148-015-0571-y

Kim Cheong-Seok 김정석 2006. "Marriage Intention Among Never-Married Men and Women in Korea미혼남녀의 결혼의향 비교분석." Korea Journal of Population Studies 한국인구 학 29.1: 57-70.

Kovács, Ramóna 2016. “A koreai konfuciánus női szerepek a Csoszon Királyság elzárkózásának időszakában (17-19. század) és a korabeli kereszténység hatása" [Korean Confucian female roles during the hermite era of Joseon (17-19 $9^{\text {th }}$ century)]. In: Birtalan Ágnes (editor in chief.) - Csáki Nelli - Takó Ferenc (eds.) Keleti kutatások. Tanulmányok az ELTE BTK Távol-keleti Intézet OTDK dolgozataiból. 2013-2015. [Eastern Researches. Studies from the papers of the National Scientific Students' Conference, ELTE Faculty of Humanities. 2013-2015]. ELTE BTK Távol-keleti Intézet, Budapest, 139-190.

Lee Jae Kyung - Kim Bo Hwa이재경- 김보화 2015. “The Prospect and Meaning of Marriage among Unmarried Women in Korea: Heterogeneity across Educational Attainment Groups 2, 30 대 비혼 여성의 결혼 전망과 의미 학력 집단 간 차이를 중심으로." Journal of Korean Women's Studies 한국여성학 31.4: 41-85.

Lee, Mijeong 1998. Women's Education, Work and Marriage in Korea. Seoul National University Press.

Lee, Mijeong 2008. "Dual earners call for family-friendly society." In: Kim Kyong-dong - The Korea Herald (eds.) Social Change in Korea. Insight into Korea Series Vol. 2. Jimoondang, 175-183.

Lee Ok-Kyung - An Young-Hea 이옥경 - 안영혜 2017. "Analysis of the State of Paternal Involvement and Barriers - The Case of the City of Busan - 아빠육아 참여 및 육아장애 요인 에 대한 인식 부산광역시를 중심으로." Korea Journal of Child Care and Education 한국 영유아보육학 107: 33-59. 
Lee Yean-Ju 이연주 2008. "Implications of Cohabitation for the Korean Family: Cohabiter Characteristics Based on National Survey Data 동거와 한국가족 전국조사에서 나타난 동거자 의 특성." Korea Journal of Population Studies 한국인구학 31.2: 77-100.

National Assembly Budget Office 2018. The reasons and the economic effects of the low birth rate in Korea (우리나라 저출산의 원인과 경제적 영향).

Ok, Kyung Yang 2003. "Family Structure and Relations." Social Indicators Research 62/63 (The Quality of Life in Korea: Comparativeand Dynamic Perspectives) 119: 121-148. https://doi. org/10.1023/A:1022689016039

Park Chul soon - Ko Eun mi 박철순 - 고은미 2018. "Analysis of Awareness and Needs for Paternal Involvement and Parenting Support Systems 아빠 육아 참여와 제도에 대한 인식 및 요구 분석.” 육아지원연구 13.1: 197-220. https://doi.org/10.16978/ecec.2018.13.1.008

Park, Hyunjoon 2013. "The Transition to Adulthood among Korean Youths: Transition Markers in Productive and Reproductive Spheres." The Annals of the American Academy of Political and Social Science, 646 (Transitioning to Adulthood in Asia: School, Work, and Family Life): 129-148. https://doi.org/10.1177/0002716212467947

Park, Hyunjoon - Choi, Jaesung 2015. "Long-term trends in living alone among Korean adults Age, gender, and educational differences." Demographic Research 32: 1177-1208. https:// doi.org/10.4054/DemRes.2015.32.43

\section{Online references}

“Chok'aege p'uk ppajin shinggŭltŭl, chok'ababo shindŭrom” 조카에 게 푹 빠진 싱글들, 조카바 보 신드롬! [Singles fallen in love with their nieces and nephews, craziness for nephews syndrome]. Life and talk. 2016.06.20. https://www.lifentalk.com/1243 (accessed: 29.03.2020.)

“'Koltŭmisŭ' twie karyŏjin 'shilbŏmisŭ”" ‘골드미스' 뒤에 가려진 '실버미스' [Silver miss unseen behind gold miss]. 헤럴드경제 Herald Economics. 2010.04.05. http://biz.heraldcorp. com/view.php?ud=20070724000096 (accessed: 28.03.2020.)

“Honsu” 혼수(婚需). Encyclopedia of Korean Culture. Academy of Korean Studies. http://encykorea.aks.ac.kr/Contents/Item/E0063906 (accessed: 27.03.2020.)

“[Kŭraep'ik] Honin'gŏnsu mit ch'ohonyŏllyŏng ch'ui” [그래픽]혼인건수 및 초혼연령 추이 [Graphic] Number of marriages and progress of age at first marriage]. Joongang Ilbo중앙일 보. 2016.12.13. https://news.joins.com/article/20996204 (accessed: 30.03.2020.)

Marriage, statistical index, KOSIS. http://kosis.kr/search $/$ search.do?query $=\% \mathrm{ED} \% 98 \% \mathrm{BC} \%$ EC\% 9D\%B8\# (30.03.2020.)

"Namjanŭn chip, yŏjanŭn honsu? 'olbarŭn kyŏrhon chunbi'e taehan saenggakŭn” 남자는 집, 여 자는 혼수? '올바른 결혼 준비'에 대한 생각은... [House from the man, honsu from the women? Thoughts about the proper marriage preparation...]. dongA.com. 2018.06.14. http:// www.donga.com/news/article/all/20180614/90584926/1 (accessed: 27.03.2020.)

“"Namp’yŏn ŏpsŏdo kwaench'ana' Nahollo kyŏrhonhanŭn 'shinggŭrwedingjok” 남편 없어 도 괜찮아" 나홀로 결혼하는 “싱글웨딩족' ["I am okay without a husband" single wedding people marrying themselves]. Money today. 2015.07.10. https://news.mt.co.kr/mtview. php?no=2015070914453931110 (accessed: 29.03.2020.)

"Namŭn chip, yŏnŭn honsu? mihonnamnyŏ modu "twaetkŏdŭnyo" 男은 집, 女는 혼수? 미 혼남녀 모두 “됐거든요” [House from the man, honsu from the woman? Unmarried women all say: no thanks]. Chosun. 2016.07.13. https://news.chosun.com/site/data/html_ dir/2016/07/13/2016071300278.html (accessed: 28.03.2020.) 
“"Nanŭn nawa kyŏrhonhanda'... shinggŭrweding sŏnt'aek'anŭn 'sollogomijok”” 나는 나와 결 혼한다”...싱글웨딩 선택하는 ‘솔로고미족' [I'm married to myself... sologomy people who choose single weddings]. 아시아경 제 Asian Economy. 2018.03.22. https://www.asiae. co.kr/article/2018032210454155706 (accessed: 29.03.2020.)

"Orininal” 어린이날 Encyclopedia of Korean Culture. Academy of Korean Studies. https://encykorea.aks.ac.kr/Contents/Item/E0035938 (accessed: 27.04.2020.)

Park Eun-jeong - An Ka-yeong: “'Gold Miss': To Be or Not To Be?” The Korea Times. 2008.07.23. https://www.koreatimes.co.kr/www/news/opinon/2013/01/162_28061.html(accessed:28.03.2020.)

"Pihaengsonyŏ" 비행소녀 [Happily unmarried young women]. https://www.mbn.co.kr/vod/programMain/746 (accessed: 29.03.2020.)

“'Pihaengsonyŏ' Kim Wansŏn, tebwi 33nyŏn mane chip ilsang ch'ŏt konggae 'pihon sam koengjanghi haengbok manjok" "비행소녀' 김완선, 데뷔 33년 만에 집·일상 첫 공개 “비 혼 삶 굉장히 행복.만족" [Not married, but happy Kim Wansun: 33 years after the debut, first reveal about home and everyday life: "quite happy and satisfied with unmarried life"]. 중앙일보 Joongang Ilbo. 2018.04.02. https://news.joins.com/article/22500908 (accessed: 29.03.2020.)

"Pihon mwŏgillae? 'Pihaengsonyŏ' ayumi-chomiryŏng·ch'oeyŏjin 'kyŏrhon? an han kŏt' 비혼 (非婚) 뭐길래?...” ‘비행소녀' 아유미·조미령·최여진 “결혼? 안 한 것” [What about not being married? Happy unmarried Ayumi, Cho Miryŏng and Ch'oe ojjin sais: I didn’t want to]. dongA.com. 2017.09.05. http://www.donga.com/news/article/all/20170905/86169826/2 (accessed: 29.03.2020.)

"[Pihon ŭi kyŏngjehak] Kyŏrhon? chashik? nae salmi chungyohajyo" [비혼(非婚)의 경제학] 결혼? 자식? 내 삶이 중요하죠 [Economy of unmarried status: Marriage? Children? My life is rather important]. 중앙일보 Joongang Ilbo. 2016.07.10. https://news.joins.com/article/20285439 (accessed: 29.03.2020.)

“Shinggŭlchogege nae chashikkat'ŭn kŭ aet't 'chok'ababo' shindŭrom” 싱글족에 게 내 자식같 은 그 애... '조카바보' 신드롬. [That child for the singles like their owns... craziness for nephews syndrome]. 아시아경제 Asian Economy. 2016.06.13. https://www.asiae.co.kr/article/2016061015545156853 (accessed: 29.03.2020.)

“[T'onggyero pon yŏsŏng] 'kyŏrhon p'ilsu' mihon yŏ 6nyŏnsae $47 \% \rightarrow 3 \%$ ” [통계로 본 여성] '결혼 필수' 미혼女 6 년새 $47 \% \rightarrow 31 \%$. [Women seen through statistics] Unmarried women seeing marriage as a must decrease in 6 years from $47 \%$ to 31\%]. Yonhap News Online. 2017.06.27. https://www.yna.co.kr/view/AKR20170627057600005 (accessed: 25.03.2020.)

Unni network. http://www.unninetwork.net/ (accessed: 30.04.2020.)

Work and Life Balance. http://www.worklife.kr/website/index/ (accessed: 27.03.2020.) 